\title{
ROLE OF NUTRITIONAL SUPPORT PROVIDED BY QUALIFIED DIETITIANS IN THE PREVENTION AND TREATMENT OF NON-COMMUNICABLE DISEASES
}

\author{
Barbara Bednarczuk ${ }^{1}$,Anna Czekajło-Kozłowska ${ }^{2}$ \\ ${ }^{1}$ Department of Dietetics, Students Scientific Club, Wroclaw Medical University, Parkowa str. 34, \\ 51-616 Wroclaw, Poland \\ ${ }^{2}$ Department of Dietetics, Wroclaw Medical University, Parkowa str. 34, 51-616 Wroclaw, Poland
}

\begin{abstract}
The role of dietitians is to counsel patients on special dietary modifications, develop dietary plans and provide dietary advice for healthy lifestyle in order to promote health and prevent disease. As lifestyle changes have become a primary reason for the increasing prevalence of non-communicable diseases in recent decades, it appears that nutritional therapy should play an important role in the multidisciplinary healthcare system. The aim of the review was to evaluate the role of nutritional support provided by dietitians in the prevention and treatment of chronic diseases in terms of its clinical and cost-effectiveness, according to their range of activity and qualifications. The evaluation was based on the review of the current literature. The costs of the treatment of non-communicable diseases encompass the costs of the treatment of the disease itself, costs of its complications and costs resulting from the decline of the productivity of patients. The results of studies indicate that nutritional support provides not only clinical but also cost benefits in the prevention and treatment of various non-communicable diseases. Every $€ 1$ spend on dietary counseling of patients with obesity or obesity-related diseases approximately returns a net $€ 14$ to $€ 63$ over a period of five years. Dietitians appear to be more effective in counseling overweight or obese patients with present risk factors compared to other specialists, however the barriers to accessing a qualified dietitian and problems with the reimbursement for services still exist. As adequate professional qualifications of dietitians appear to be an important factor determining the effectiveness of implemented dietary care, an additional training courses for dietitians and enhanced cooperation of hospitals and medical universities are needed.
\end{abstract}

Key words: dietitians, dietary counseling, cost effectiveness, clinical effectiveness, non-communicable diseases

\section{STRESZCZENIE}

Rola dietetyka polega na pomaganiu pacjentom we wdrażaniu odpowiednich zmian w sposobie żywienia, opracowywaniu indywidualnych jadłospisów, a także poradnictwie żywieniowym w zakresie zdrowego stylu życia w celu zachowania zdrowia i prewencji chorób. Ponieważ zmiany stylu życia stały się w ostatnim czasie główną przyczyną rosnącej liczby zachorowań na choroby niezakaźne, wydaje się, że poradnictwo żywieniowe powinno odgrywać istotną rolę w multidyscyplinarnym systemie opieki zdrowotnej. Celem artykułu była ocena roli wsparcia żywieniowego udzielanego przez dietetyków w prewencji i leczeniu przewlekłych chorób niezakaźnych w kontekście jej efektywności klinicznej i ekonomicznej, w zależności od zakresu działania i kwalifikacji posiadanych przez specjalistów z zakresu żywienia. Oceny dokonano na podstawie danych uzyskanych z przeglądu piśmiennictwa naukowego z ostatnich lat. Koszty leczenia chorób przewlekłych ogółem obejmują takie składowe jak: koszty leczenia samej choroby, koszty leczenia powstałych komplikacji oraz koszty wynikające z utraty produktywności pacjentów. W badaniach wykazano, że prowadzenia terapii żywieniowej związane jest z nie tylko klinicznymi, ale również ekonomicznymi korzyściami w prewencji i leczeniu przewlekłych chorób niezakaźnych. Każde 1 euro wydane na poradnictwo dietetyczne pacjentów z otyłością lub chorobami wynikającymi z nadmiernej masy ciała skutkuje zyskiem netto w wysokości nawet 14-63 euro w ciągu pięciu lat. Dietetycy wydają się być bardziej skuteczni w prowadzeniu terapii żywieniowej w grupie pacjentów z nadwagą lub otyłością z istniejącymi czynnikami ryzyka chorób sercowo-naczyniowych w porównaniu z innymi specjalistami ochrony zdrowia, jednak nadal istotny problem stanowi brak dostępności do wykwalifikowanych dietetyków oraz brak możliwości zwrotu kosztów poradnictwa żywieniowego. Jako że odpowiednie kwalifikacje zawodowe dietetyków wydają się być ważnym

Corresponding author: Anna Czekajło-Kozłowska, Department of Dietetics, Wroclaw Medical University, Parkowa str. 34, 51-616 Wroclaw, Poland. e-mail: anna.czekajlo-kozlowska@umed.wroc.pl

(C) Copyright by the National Institute of Public Health - National Institute of Hygiene 
czynnikiem decydującym o efektywności prowadzonej terapii, niezbędne jest wprowadzenie kursów doszkalających dla dietetyków oraz zintensyfikowanie współpracy pomiędzy szpitalami i uczelniami medycznymi.

Słowa kluczowe: dietetycy, poradnictwo żywieniowe, korzyści kliniczne, korzyści ekonomiczne, przewlekłe choroby niezakaźne

\section{INTRODUCTION}

Improper diet is an established risk factor for most of the non-communicable diseases, including cardiovascular diseases (CVD), diabetes (DM) type II and cancer. According to the International Diabetes Federation (IDF) 451 million adults were living with DM type 2 in 2017; this number is expected to increase to 693 million in 2045 [4]. Based on the data from the NCD Risk Factor Collaboration study, 50 (24-89) million girls and 74 (39-125) million boys were obese in 2016 [21]. Overall, more than 2.1 billion people are overweight or obese worldwide, while excessive body mass is the fifth leading cause of death in the world, accounting for approximately 3.4 million deaths annually [32]. It was estimated that adequate dietary habits, maintaining normal body mass and physical activity might have prevented from 5 to $34 \%$ of oral, throat, esophagus, stomach and colon cancer cases [23].

As lifestyle changes have become a primary reason for the increasing prevalence of non-communicable diseases in recent decades, it appears that qualified dietitians should be a vital part on the multidisciplinary healthcare team. The main role of dietitians is to counsel patients on special dietary modifications, develop dietary plans, provide dietary advice for healthy lifestyle and promote health and prevent disease [34]. Nonetheless, the actual functioning of the nutritional care varies across the world and the number of dietetics hired in the hospital wards is often insufficient. This is thus a serious, though often overlooked problem, because nutrition therapy may provide clinical and cost benefits for management of various non-communicable diseases.

The aim of the review was to evaluate the role of nutritional support provided by dietitians in the prevention and treatment of chronic diseases in terms of its clinical and cost-effectiveness, according to their range of activity and qualifications.

\section{COSTS OF TREATMENT OF NON-COMMUNICABLE DISEASES IN EUROPE AND UNITED STATES}

Costs of the treatment of non-communicable diseases are extremely high expenses of the healthcare system. These costs diseases should be considered in several aspects: as costs of the treatment of the disease itself, costs of its complications and costs resulting from the decline of the productivity of patients, including their premature mortality.

According to the American Heart Association, the annual cost of CVD and stroke in United States was estimated at $\$ 316.1$ billion, including approximately $\$ 189.7$ billion of directs costs (cost of health professionals, hospital services, medication and home health care) and $\$ 126.4$ billion of indirect costs associated with the lost future productivity due to premature CVD and stroke mortality in 2012 to 2013 [2]. The costs of obesity were estimated at $\$ 147$ billion in 2008, compared to $\$ 79$ billion per year in 1998 [8].

In Germany the overall cost per first-year survivor was estimated at $€ 18,517$ for the first-ever ischemic stroke. Lifetime cost per individual was about $€ 43,129$ which corresponds to the overall cost of $€ 51.5$ billion in men and $€ 57.1$ billion in women by 2025 [15]. Köster et al. [16] observed a continuous increase in the prevalence of diabetes mellitus type 2 in German population; total direct health expenditure due to DM type 2 rose from $€ 27.8$ billion to $€ 42.0$ billion $(+51.1 \%)$ in years $2000-2007$.

Scarborough et al. [28] estimated that in 20062007 diet-related costs amounted to $£ 5.8$ billion in United Kingdom, compared to $£ 3.3$ billion related to smoking, £3.3 billion related to alcohol consumption and £5.1 billion linked with overweight and obesity. Emery et al. [7] showed that the average annual healthcare costs in France for obese subjects were $€ 2500$ per person, twice the costs for normal-weight individuals (€1263). In analysis adjusted for age, sex, socioeconomic status, alcohol intake and smoking status, the additional annual cost of obesity varied from $€ 506$ to $€ 648$ per person in comparison with normal-weight subjects.

Hermanowski et al. [9] calculated the costs associated with hypertension prevalence in Poland. The average annual cost per a hypertensive patient was 1570 PLN. According to the authors of the study, the total burden of hypertension may reach 14 billion PLN per year, including doctor's consultations (30.8\%), productivity losses $(26.6 \%)$, hospitalizations (21.0\%), laboratory and diagnostic tests (11.4\%) and pharmacological treatment (10.2\%). In another study Paczkowska et al. [24] observed that the average total cost of treatment of hypertension per patient amounted to approximately 3494 PLN per year while the structure of the costs was as follows: medications - $71 \%$, doctor's consultations and tests - 14\%, hospitalizations $-7 \%$, transport of the patient $-5 \%$ 
and loss productivity $-3 \%$. In a study performed by Kinalska et al. [14] in a group of 303 patients with DM type 2, the overall annual treatment costs per patient were estimated at 9227.2 PLN, including approximately 2430 PLN of directs costs. Paramedics consultations, including dietary counseling, provided $2.9 \%$ of direct costs.

\section{CLINICAL AND COST BENEFITS FOR NUTRITIONAL MANAGEMENT OF NON-COMMUNICABLE DISEASES}

In recent years, the effectiveness of the nutritional therapy was analyzed in the context of its clinical and cost benefits in various types of medical conditions.

Sikand et al. [31] assessed the clinical and cost benefits of medical nutrition therapy provided by registered dietitian nutritionists for management of dyslipidemia. Authors observed that nutrition therapy improved quality-adjusted life years $(+0.75$ to +0.78 years) and reduced drug use causing cost savings of $\$ 638$ to $\$ 1456$ per patient per year. Moreover, dietary consultations improved clinical outcomes: lowered total and LDL-cholesterol levels by $6 \%$ to $11 \%$, lowered triglyceride levels by $11 \%$ to $22 \%$, raised HDL cholesterol levels by $4 \%$ and lowered BMI by $4 \%$. Increased time spent with the registered nutritionist was associated with greater improvements.

Wood et al. [37] performed a paired, clusterrandomized controlled trial in eight European countries (EUROACTION) in order to assess whether a nurse-coordinated multidisciplinary, family-based preventive cardiology program might provide benefits in preventive care in clinical practice. After one year of the study, reduced intake of saturated fat $(55 \%$ vs. $40 \% ; \mathrm{p}=0.0009$ ) and an increased consumption of fruit and vegetables ( $72 \%$ vs. $35 \%$; $=0.004)$ and oily fish $(17 \%$ vs. $8 \%$; $p=0.04)$ was observed in an intervention group in comparison with a control group. Nutritional education in this study was delivered by nurses instead of qualified dietitians.

In a study performed by Sun et al. [35] the effectiveness and cost of nutritional education for diabetes prevention was estimated. In a group of participants receiving intervention with nutritional education a reduction of body mass of $2.07 \mathrm{~kg}(95 \%$ CI $1.52-2.62 ; \mathrm{p}<0.0001)$ at 12 months was found. Higher relative weight loss was observed in a group of individuals who obtained education from a dietitian compared to a non-dietitian. Intervention delivery channel (in person vs. technology-delivered) was not an important predictor of weight loss. The cost of intervention per kilogram weight loss ranged from $\$ 34.06$ to $\$ 1,005.36$ over 6-12 months and was lower if the intervention was delivered by dietitian in comparison with non-dietitian.
Cho et al. [5] evaluated the effect of nutritional education in a group of patients with DM type 2. In the group who received intensive nutritional education (three visits during 6-month clinical trial, 96.4 \pm 12.2 $\mathrm{min} /$ person) a significant reduction of body weight, systolic blood pressure and glycated hemoglobin concentration was observed $(\mathrm{p}<0.05)$. Subjects from the group who only received a single visit with a dietitian (67.9 $\pm 9.3 \mathrm{~min} /$ person) did not achieve any apparent health benefit. However, in both groups the ratio of energy intake to prescribed energy intake was decreased after the study period which might result in future weight loss.

In the Indian Diabetes Prevention Programme (IDPP) performed in group of Asian Indians both lifestyle modification and metformin were costeffective interventions for preventing diabetes type II among subjects with impaired glucose tolerance in India. The cost of prevention of one case of diabetes with lifestyle changes was $\$ 1,052$, with metformin $\$ 1,095$, while with both interventions - $\$ 1,359$ [26].

Based on the results of the systemic review of twenty-six randomized control trials, dietary consultations for adults in primary care appear to be particularly effective for improvement in diet quality, weight loss, diabetes outcomes and limitation of gestational weight gain. The effectiveness of direct dietetic counseling alone with reference to blood pressure and plasma lipid levels remains inconclusive [19].

According to the SEO Economic Research report on the cost-effectiveness of dietary treatment commissioned by Dutch Association of Dietitians in 2012, patients treated by a dietitian took an average of 0.92 day of sick leave due to their condition (excessive weight or diabetes) during the treatment year. Individuals who only received a written information took an average of 3.49 days. This large difference (2.58 working days a year) in case of 100 employees may lead to a total of 26 days decreased productivity per year. It appears that for every $€ 1$ spend on nutritional counselling society gets a net benefits of $€ 14$ to $€ 63$ over a period of five years, including $€ 56$ in terms of improved health, $€ 3$ net savings in total health care costs and $€ 4$ in terms of productivity gains. Based on another analysis, $€ 1$ spent on medical intervention approximately returns a net $€ 3$ to $€ 5$, which indicated that dietary counselling is very cost-effective in comparison with other medical treatments. Overall, the dietary treatment of individuals with obesity and comorbidities such as diabetes, hypertension, hyperlipidemia or hypercholesterolemia might gain $€ 0.4$ to $€ 1.9$ billion over a period of five years [18].

The results of the systemic review performed by Patnode et al. [25] indicate that dietary interventions for adults without known hypertension, dyslipidemia, 
diabetes, impaired fasting glucose or glucose tolerance resulted in only modest benefits concerning the reduction of blood pressure, LDL and total cholesterol levels and adiposity as well as the modification of dietary behavior. Higher intensity interventions resulted in greater improvements. However, as harmful effects of these interventions do not basically exist, it may be concluded that dietary changes might lead to long-term reduction in cardiovascular events if continued for a long time.

Apart from the therapy of cardiovascular risk factors, dietary counseling should play an important role in the prevention and treatment of malnutrition. Beck et al. [1] investigated whether adding a dietitian to the liaison team after discharge of geriatric patients improves their nutritional status, muscle strength, functional status and quality of life, use of social services, re-/hospitalization and mortality. In a study of 71 patients $70+$ years old and at nutritional risk authors found that nutritional counseling (three home visits per patient) in this group may improve the nutritional status and reduce the number of hospitalizations within 6 months. In a study of Shang et al. [30] the reduction of complications (88\%) and cost saving (98\%) have been observed since the nutritional support teams were established in selected hospitals in Germany, Austria and Switzerland. Kruizenga et al. [17] found that early screening and dietary treatment of malnourished patients with low handgrip strength (adding approximately $600 \mathrm{kcal}$ and $12 \mathrm{~g}$ protein to their daily diet) reduced the length of their stay in hospital. The cost of nutritional care needed to shorten the mean length of hospital stay by one day for all malnourished patients was $\$ 91$. Moreover, according to Morán López et al. [20] proper detection of disease related malnutrition might prevent the loss of $16.8 \%$ of health expenses (approximately €424.785) and justify $€ 343.291$ reimbursement for nutritional diagnoses and processes.

\section{EFFECTIVENESS OF DIETITIANS COMPARED WITH OTHER HEALTHCARE WORKERS}

Since dietitians have specialized knowledge about the associations between diet and health outcomes, dietary treatment delivered by a dietitian should be more effective in improving health than dietary advices given by medical doctors and other healthcare workers. However, it is worth mentioning that professional dietitians and general practitioners (GPs) and nurses have other target group of patients. Moderately overweight individuals (BMI $25-30 \mathrm{~kg} /$ $\mathrm{m}^{2}$ ) without any comorbidities can obtain dietary recommendations from their GP, nurse or weight consultant, but it appears that overweight or obese subjects with present risk factors and/or comorbidity would benefit from the consultation with a specialist dietitian [18].

In a metaanalysis performed by Thompson et al. [36] individuals with high cholesterol level and related comorbidities receiving dietary advices from dietitians experienced greater reduction of blood cholesterol level in comparison with those receiving dietary advices only from doctors $(-0.25 \mathrm{mmol} / \mathrm{L} ; 95 \%$ CI $-0.37--0.12 \mathrm{mmol} / \mathrm{L})$. Jebb et al. [13] observed that overweight individuals with minor comorbidities assigned to the commercial programme Weight Watchers who completed the 12-month assessment (on average two or three meetings per month) experienced higher weight loss compared to subjects assigned to standard care (one visit to general practitioner per month) $(-6.65 \mathrm{~kg}$ vs. $-3.26 \mathrm{~kg})$. On the other hand, Nightingale and Reeves [22] showed that dietitians scored better than other groups, including doctors, nurses and pharmacists, in a questionnaire about the assessment and management of undernutrition.

The emphasis on dietary care does not devalue the role of medical doctors in the lifestyle modifications of the overall population. Inversely, doctor's recommendation was found to be the reason of even $90 \%$ of dietitian appointments [18]. Motivations to eat healthily vary in different socioeconomic and diseaserelated groups so medical visit is an important factor increasing the awareness of the relationship between dietary habits and health and leading to dietary changes [6]. Nonetheless, standard doctor's appointment time is too short to entirely assess dietary habits, recommend adequate diet and educate the patient, which usually takes a dietitian at least one hour per visit [5].

A positive effect of nutritional therapy conducted not only by a dietitian, butalso otherhealth professionals was observed [31, 33]. Although the implementation of healthy dietary habits itself is beneficial for patients, providing dietary counseling by other specialists than dietitians should not be considered in terms of costsaving due to the need of the appropriate nutritional training of the medical personnel, which also involves costs.

\section{CURRENT DIFFICULTIES AND PERSPECTIVES FOR THE FUTURE}

At the end of the '90s Howard et al. [11] emphasized that an agreement about the key functions of the dietitians working in nutritional support, as well as common standards and educational requirements for all dietitians are needed. The results of studies appear to support this opinion, indicating that qualified dietitians have better particular knowledge about nutrition-related issues compared with other health professionals and should not be replaced by other specialists. Dietary management seems particularly 
important in group of patients with elevated blood glucose levels. Major medical and health organizations agree that medical nutrition therapy provided by registered dietitians in adults with prediabetes or type 2 diabetes is clinically and cost effective. However, the barriers to accessing a specialist and problems with the reimbursement for services still exist [3]. Robbins et al. [27] observed that only $9.1 \%$ of diabetic patients of the Philadelphia Health Care Centers had at least one nutritionist visit within a 9-year period. What is more, health insurance policies usually do not cover dietary treatment of non-communicable diseases and do not indicate dietitians as providers of nutritional education.

Nonetheless, it appears that although more dietitians have recently the opportunity to play a leading role within the nutritional care team for the screening and treatment of diet-related conditions, the basic training and lack of experience often do not allow them to do it effectively [29]. According to the International Confederation of Dietetic Associations (ICDA) report in 2016 the professional title was protected by law only in 33 out of 42 membership countries. The minimum level of education varied from no basic education to master's degree, although the actual time taken to receive the degree varied from less than three years to five years [12].

Based on the report on the cost-effectiveness of dietary treatment, nutritional management should be a part of the basic care package. This would not only generate the net savings of the therapy of overweight patients with existing comorbidities (in the context of lowered costs of hospital visits and medications in the future) but also increase the awareness of the role of the diet in maintaining health in the overall population, what may lead to long-term reduction in cardiovascular events [18]. In order to provide patients with the best possible dietary treatment, additional training courses for dietitians and enhanced cooperation of hospitals and medical universities in the context of effective student work placements are needed [10,29].

\section{CONCLUSIONS}

The results of presented studies unequivocally indicate that nutritional support provides clinical and cost benefits in prevention and treatment of various non-communicable diseases. Adequate professional qualifications of dietitians appear to be an important factor determining the effectiveness of implemented dietary care.

\section{Conflict of interest}

The authors declare no conflict of interest.

\section{REFERENCES}

1. Beck A., Andersen U.T., Leedo E., Jensen L.L., Martins K., Quvang M., Rask K.Ø., Vedelspang A., Rønholt F.: Does adding a dietician to the liaison team after discharge of geriatric patients improve nutritional outcome: a randomised controlled trial. Clin Rehabil 2015;29(11):1117-1128, doi: 10.1177/0269215514564700.

2. Benjamin E.J., Blaha M.J., Chiuve S.E., Cushman M., Das S.R., Deo R., de Ferranti S.D., Floyd J., Fornage M., Gillespie C., Isasi C.R., Jiménez M.C., Jordan L.C., Judd S.E., Lackland D., Lichtman J.H., Lisabeth L., Liu S., Longenecker C.T., Mackey R.H., Matsushita K., Mozaffarian D., Mussolino M.E., Nasir K., Neumar R.W., Palaniappan L., Pandey D.K., Thiagarajan R.R., Reeves M.J., Ritchey M., Rodriguez C.J., Roth G.A., Rosamond W.D., Sasson C., Towfighi A., Tsao C.W., Turner M.B., Virani S.S., Voeks J.H., WilleyJ.Z., Wilkins J.T., Wu J.H., Alger H.M., Wong S.S., Muntner P., American Heart Association Statistics Committee and Stroke Statistics Subcommittee.: Heart disease and stroke statistics-2017 update: a report from the American Heart Association. Circulation. 2017;135(10):e146-e603, doi:10.1161/ CIR.0000000000000485.

3. Briggs K., Stanley K.: Position of the Academy of Nutrition and Dietetics: The role of medical nutrition therapy and registered dietitian nutritionists in the prevention and treatment of prediabetes and type 2 diabetes. J Acad Nutr Diet 2018;118(2):343-353, doi: 10.1016/j.jand.2017.11.021.

4. Cho N.H., Shaw J.E., Karuranga S., Huang Y., da Rocha Fernandes J.D., Ohlrogge A.W., Malanda B.: IDF Diabetes Atlas: Global estimates of diabetes prevalence for 2017 and projections for 2045. Diabetes Res Clin Pract 2018;138:271-281, doi:10.1016/j. diabres.2018.02.023.

5. Cho Y., Lee M., Jang H., Rha M., Kim J., Park Y., Sohn $C .:$ The clinical and cost effectiveness of medical nutrition therapy for patients with type 2 diabetes mellitus. Korean J Nutr 2008;41(2):147-155 [in Korean].

6. Dijkstra S.C., Neter J.E., Brouwer I.A., Huisman M., Visser M.: Motivations to eat healthily in older Dutch adults - a cross sectional study. Int J Behav Nutr Phys Act 2014;11:141, doi.org/10.1186/s12966-014-0141-9.

7. Emery C., Dinet J., Lafuma A., Sermet C., Khoshnood F.F.: Évaluation du coût associé à l'obésité en France [Cost of obesity in France] La Presse Médicale 2007;36(6-C1):832-840, doi:10.1016/j. lpm.2006.12.031 (in French).

8. Finkelstein E.A., Trogdon J.G., Cohen J.W., Dietz W.: Annual medical spending attributable to obesity: payerand service-specific estimates. Health Aff (Millwood) 2009;28(5):w822-31, doi: 10.1377/hlthaff.28.5.w822.

9. Hermanowski T., Jaworski R., Czech M., Pachocki $R$.: Ocena kosztów związanych $\mathrm{z}$ występowaniem nadciśnienia tętniczego w Polsce [Costs of hypertension in Poland]. Arterial Hypertension 2001;5(2):83-91 (in Polish). 
10. Hickson M., Child J., Collinson A.: Future Dietitian 2025: informing the development of a workforce strategy for dietetics. J Hum Nutr Diet 2018;31(1):2332, doi:10.1111/jhn.12509.

11. Howard J.P., Jonkers-Schuitema C.F., Kyle U.: The role of the nutritional support dietitian in Europe. Clin Nutr 1999; 18(6):379-383.

12. International Confederation of Dietetic Associations: 2016 Study report Dietitians-nutritionists around the World. Available at: https://www.internationaldietetics. org/Downloads/2016-ICDA-Education---Work-report. aspx (Accessed 21.02.2019).

13. Jebb S.A., Ahern A.L., Olson A.D., Aston L.M., Holzapfel C., Stoll J., Amann-Gassner U., Simpson A.E., Fuller N.R., Pearson S., Lau N.S., Mander A.P., Hauner H., Caterson I.D.: Primary care referral to a commercial provider for weight loss treatment versus standard care: a randomised controlled trial. Lancet 2011;378(9801):1485-1492, doi: 10.1016/S01406736(11)61344-5.

14. Kinalska I., Niewada M., Głogowski C., Krzyżanowska A., Gierczyński J., Łatek M., Kamiński B.: Koszty cukrzycy typu 2 w Polsce(Badanie CODIP) [Cost of Diabetes Type 2 in Poland (CODIP)]. Diabetologia Praktyczna 2004;5(1):1-8.

15. Kolominsky-Rabas P.L., Heuschmann P.U., Marschall D., Emmert M., Baltzer N., Neundörfer B., Schöffski O., Krobot K.J.: Lifetime cost of ischemic stroke in Germany: results and national projections from a population-based stroke registry: the Erlangen Stroke Project. Stroke 2006;37(5):1179-1183, doi: 10.1161/01. STR.0000217450.21310.90.

16. Köster I., Huppertz E., Hauner H., Schubert I.: Direct costs of diabetes mellitus in Germany - CoDiM 20002007. Exp Clin Endocrinol Diabetes 2011;119(6):377385, doi:10.1055/s-0030-1269847.

17. Kruizenga H.M., Van Tulder M.W., Seidell J.C., Thijs A., Ader H.J., Van Bokhorst-de van der Schueren M.A.: Effectiveness and cost-effectiveness of early screening and treatment of malnourished patients. Am J Clin Nutr 2005;82(5):1082-1089, doi: 10.1093/ajcn/82.5.1082.

18. Lammers M., Kok L.: Cost-benefit analysis of dietary treatment. SEO Report No. 2012-76A. Amsterdam, SEO ECONOMIC RESEARCH, 2012. Available https://www.bda.uk.com/improvinghealth/ healthprofessionals/cost_benefit_of_dietitians (Accessed 21.02.2019).

19. Mitchell L.J., Ball L.E., Ross L.J., Barnes K.A., Williams L.T.: Effectiveness of dietetic consultations in primary health care: a systematic review of randomized controlled trials. J Acad Nutr Diet 2017;117(12):19411962, doi: 10.1016/j.jand.2017.06.364.

20. Morán López J.M., Piedra León M., Beneitez Moralejo B., Enciso Izquierdo F.J., Luengo Pérez L.M., Amado Señaris J.A.: Efficiency, cost-effectiveness and need of inversion in nutritional therapy. Importance of detecting and documenting undernutrition. Clin Nutr ESPEN 2016;13:e28-e32, doi: 10.1016/j.clnesp.2016.03.004.

21. NCD Risk Factor Collaboration.: Worldwide trends in body-mass index, underweight, overweight, and obesity from 1975 to 2016: a pooled analysis of 2416 populationbased measurement studies in 128.9 million children, adolescents, and adults. Lancet 2017;390(10113):26272642, doi:10.1016/S0140-6736(17)32129-3.

22. Nightingale J.M., Reeves J.: Knowledge about the assessment and management of undernutrition: a pilot questionnaire in a UK teaching hospital. Clin Nutr. 1999;18(1):23-27.

23. Norat T., Scoccianti C., Boutron-Ruault M.C., Anderson A., Berrino F., Cecchini M., Espina C., Key T., Leitzmann M., Powers H., Wiseman M., Romieu I.: European code against cancer 4th edition: diet and cancer. Cancer Epidemiol 2015;39 Suppl 1:S56-66, doi:10.1016/j.canep.2014.12.016.

24. Paczkowska A., Bryl W., Hoffmann K., Nowakowska E., Koligat D., Kus K., Zaprutko T., Ratajczak P.: Analiza kosztów leczenia nadciśnienia tętniczego w Polsce [Costs analysis of arterial hypertension treatment in Poland]. Nowiny Lekarskie 2012;81(2):145-151 (in Polish).

25. Patnode C.D., Evans C.V., Senger C.A., Redmond N., Lin J.S.: Behavioral counseling to promote a healthful diet and physical activity for cardiovascular disease prevention in adults without known cardiovascular disease risk factors: updated systematic review for the U.S. Preventive Services Task Force. JAMA 2017;318(2):175-193, doi: 10.1001/jama.2017.3303.

26. Ramachandran A., Snehalatha C., Yamuna A., Mary S., Ping Z.: Cost-effectiveness of the interventions in the primary prevention of diabetes among Asian Indians: within-trial results of the Indian Diabetes Prevention Programme (IDPP). Diabetes Care 2007;30(10):25482552, doi: 10.2337/dc07-0150.

27. Robbins J.M., Thatcher G.E., Webb D.A., Valdmanis V.G.: Nutritionist visits, diabetes classes, and hospitalization rates and charges. Diabetes Care 2008,31(4):655-660, doi:10.2337/dc07-1871.

28. Scarborough P., Bhatnagar P., Wickramasinghe K.K., Allender S., Foster C., Rayner M.: The economic burden of ill health due to diet, physical inactivity, smoking, alcohol and obesity in the UK: an update to 2006-07 NHS costs. J Public Health (Oxf) 2011;33(4):527-535, doi:10.1093/pubmed/fdr033.

29. Seignez B., Seguy D.: Place du diététicien dans l'équipe de soutien nutritionnel : évolution d'une profession. Cah Nutr Diet 2005;40:103-108 (in French).

30. Shang E., Hasenberg T., Schlegel B., Sterchi A.B., Schindler K., Druml W., Koletzko B., Meier R.: An European survey of structure and organisation of nutrition support teams in Germany, Austria and Switzerland. Clin Nutr 2005;24(6):1005-1013, doi: 10.1016/j.clnu.2005.07.005.

31. Sikand G., Cole R.E., Handu D., deWaal D., Christaldi J., Johnson EQ., Arpino L.M., Ekvall S.M.: Clinical and cost benefits of medical nutrition therapy by registered dietitian nutritionists for management of dyslipidemia: A systematic review and meta-analysis. J Clin Lipidol 2018;12(5):1113-1122, doi:10.1016/j.jacl.2018.06.016.

32. Smith K.B., Smith M.S.: Obesity statistics. Prim Care 2016;43(1):121-135, doi:10.1016/j.pop.2015.10.001. 
33. Sović N., Pająk A., Jankowski P., Duenas A., KaweckaJaszcz K., Wolfshaut-Wolak R., Stepaniak U., Kawalec $P .:$ Cost-effectiveness of a cardiovascular disease primary prevention programme in a primary health care setting. Results of the Polish part of the EUROACTION project. Kardiol Pol 2013;71(7):702-711, doi:10.5603/ KP.2013.0157.

34. Stitzel K.F., American Dietetic Association.: Position of the American Dietetic Association: the roles of registered dietitians and dietetic technicians, registered in health promotion and disease prevention. J Am Diet Assoc 2006;106(11):1875-1884, doi: 10.1016/j. jada.2006.08.009.

35. Sun Y., You W., Almeida F., Estabrooks P., Davy B.: The effectiveness and cost of lifestyle interventions including nutrition education for diabetes prevention: a systematic review and meta-analysis. J Acad Nutr Diet 2017;117(3):404-421.e36., doi:10.1016/j. jand.2016.11.016.
36. Thompson R.L., Summerbell C.D., Hooper L., Higgins J.P., Little P.S., Talbot D., Ebrahim S.: Dietary advice given by a dietitian versus other health professional or self-help resources to reduce blood cholesterol. Cochrane Database Syst Rev 2003;(3):CD001366, doi: 10.1002/14651858.CD001366.

37. Wood D.A., Kotseva K., Connolly S., Jennings C., Mead A., Jones J., Holden A., De Bacquer D., Collier T., De Backer G., Faergeman O., EUROACTION Study Group.: Nurse-coordinated multidisciplinary, familybased cardiovascular disease prevention programme (EUROACTION) for patients with coronary heart disease and asymptomatic individuals at high risk of cardiovascular disease: a paired, cluster-randomised controlled trial. Lancet 2008;371(9629):1999-2012, doi:10.1016/S0140-6736(08)60868-5.

Received: 12.03 .2019

Accepted: 06.07.2019 